\title{
ION-PAIR RECOGNITION BY DITOPIC MACROCYCLIC RECEPTORS
}

\author{
BRADLEY D. SMITH \\ Department of Chemistry and Biochemistry \\ University of Notre Dame \\ Notre Dame IN 46556 USA
}

\section{Introduction}

Over the past thirty years, a large number of macrocyclic receptors have been synthesized and evaluated for their abilities to bind cations. More recently, increased attention has been directed towards receptors for anions. Many of these synthetic receptors are uncharged molecules and operate in organic solvents. Under these conditions the target salts exist as associated ion-pairs which can hinder the single-ion recognition process. [1] A strategy to circumvent this problem is to design a single receptor with specific cation and anion binding sites. In other words, a heteroditopic receptor that can simultaneously bind both of the salt ions. The chronological development of salt receptors has been reviewed a number of times in the past few years, [2-6] and so the exercise will not be repeated here. Instead, the chapter will focus on the more specific topic of ion-pair recognition.

\section{Ditopic Receptors for Separated Ions}

Most salt receptors in the literature bind the cation and the anion as spatially separated ions. Early examples are receptors $\mathbf{1}$ and $\mathbf{2}$ that were developed by groups lead by Reinhoudt, [7] and Beer, [8] respectively. In both cases, the metal cation binds to the crown ether rings and the anion binds simultaneously to the Lewis acidic uranyl center in the case of $\mathbf{1}$, and to the amide $\mathbf{N H}$ residues in the case of $\mathbf{2}$. A more recent example is Kilburn's ditopic receptor $\mathbf{3}$ which coordinates the metal cation via the calixarene oxygens, and binds the anion in a hydrogen bonding pocket formed by the two thiourea groups. [9] A conceptually different receptor for separated ions is Gellman's macrocyclic phosphine oxide 3. [10] Hydrogen bonding with a monoalkylammonium cation on one face of the macrocycle induces receptor polarization and preorganization which promotes association with a $\mathrm{Cl}^{-}$counter-ion on the reverse face. In other words, the receptor is inserted between the two ions. 


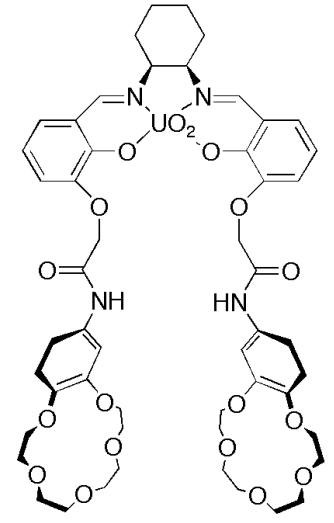

1

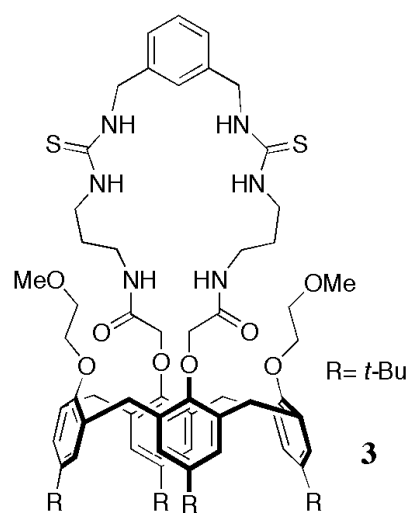

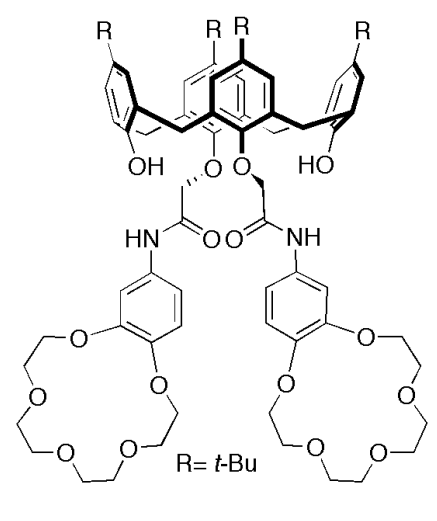

2

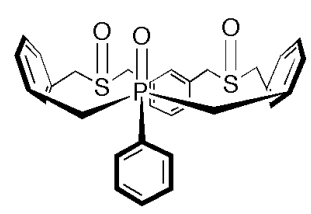

4

A fascinating property with some of these ditopic salt receptors is the feature of complexation by induced fit; that is, the binding of one ion induces a major conformational change in the receptor such that affinity for the counter-ion is improved. The mechanism is conceptually related to the allosteric action of enzymes and biological receptors. Two examples are illustrated here. The first is the Lockhart system $\mathbf{5}$ where the central polyamine linker wraps around $\mathrm{a} \mathrm{Cl}^{-}$anion which brings the two benzo-5crown-15 ether rings together and allows them to bind a $\mathrm{K}^{+}$cation. [11] The second example is Kubo's receptor 6 which acts in reverse, that is, the dibenzo-30-crown-10 wraps around $\mathrm{K}^{+}$cation and forms a preorganized binding pocket for a phosphate dianion. [12]

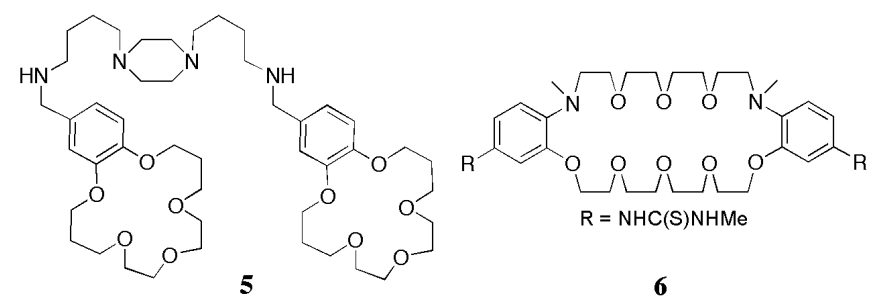




\section{Ditopic Receptors for Associated Ion-Pairs}

A potential drawback with ditopic receptors that bind salts as separated ions is the Coulombic penalty that must be paid to enforce charge separation. This problem is circumvented if the receptor binds the salt as an associated ion-pair; thus, ditopic receptors for associated ion-pairs are expected to have generally superior affinities. However, the design of convergent heteroditopic receptors is quite a challenge because the ion binding sites have to be incorporated into a suitably preorganized scaffold that holds them in close proximity, but not so close that the sites interact. One of the first successful examples of a ditopic salt receptor for associated ion-pairs is compound 7 reported by Reetz. [13] The Lewis acidic boron atom can form a reversible dative bond with a $\mathrm{F}^{-}$anion which promotes simultaneous coordination of a $\mathrm{K}^{+}$cation by the oxygen atoms in the surrounding crown ether. Other early examples are the Kilburn macrobicycle 8, which appears to bind the mono-potassium salts of dicarboxylic acid acids as contact ion-pairs, [14] and our receptor 9 which was shown by X-ray diffraction to complex $\mathrm{NaCl}$ as a solvent separated ion-pair. [15] More recently, the Beer group has reported that macrocycle $\mathbf{1 0}$ is able bind an organic ion-pair in solution and form the pseudo rotaxane 11. [16]

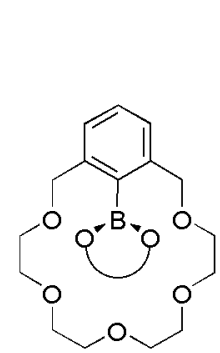

7

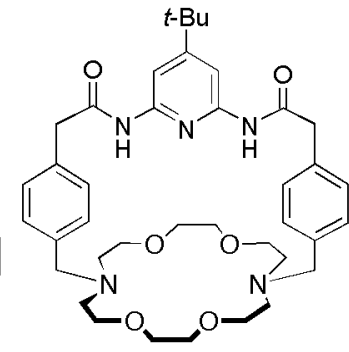

8

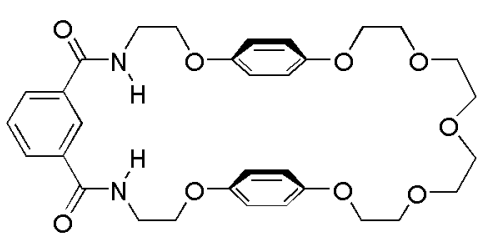

10

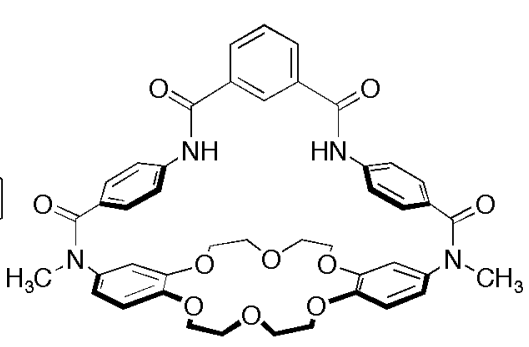

9

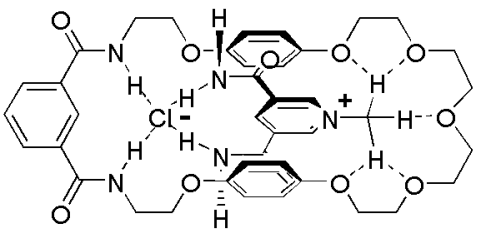

11

A growing area of supramolecular research is the topic of controlled selfassembly, and a number of groups have shown how salts can be used to template the dimerization of receptors with water often acting as a stabilizing agent. [17,18] In some cases, the assembled aggregate is large enough to act as a capsule and completely encapsulate both ions of the salt. [19] A related design is the so-called "venus fly trap" capsule. An example of this design was recently reported by Atwood and coworkers, 
who showed that an extended, deep-cavity resorcinarene derivative can completely encapsulate a $\mathrm{NMe}_{4}{ }^{+}$cation with a $\mathrm{Cl}^{-}$anion positioned by hydrogen bonding at the capsule entrance (see schematic receptor 12). [20]

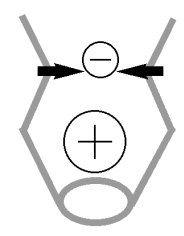

12

\section{Ion-Pair Recognition Using Ditopic Receptor 13}

As stated above, the most effective way to enhance salt binding by electrostatic effects is to use a receptor that binds the salt as a contact ion-pair. In 2001, our group prepared the simple ditopic receptor $\mathbf{1 3}$ and evaluated its ability to bind salts as associated ion-pairs (Scheme 1). We discovered that the receptor is able to extract a wide range of monovalent salts into weakly polar solvents. Furthermore, the resulting receptor/salt complexes are very stable. For example, most can survive column chromatography using silica gel and weakly polar solvents. Shown in Figure 1 is a series of ${ }^{1} \mathrm{H}$ NMR spectra that monitor the receptor mediated extraction of $\mathrm{KCl}$ into $\mathrm{CDCl}_{3}$. Note that the exchange of salt between occupied and unoccupied receptor is slow on the NMR time scale; thus, the complexation system provides a unique opportunity to investigate the structure and dynamics of an isolated, associated ion-pair. After each extraction is completed, the uncomplexed salt is removed by filtration, and the filtrate evaporated to leave the 13/salt complex as a solid residue which most times can be readily recrystallized. The resulting $\mathrm{X}$-ray structures provide high-resolution pictures of the complexes, and the following sections illustrate the mechanisms that receptor $\mathbf{1 3}$ employs to recognize a wide range of salts with different shapes and coordination properties.

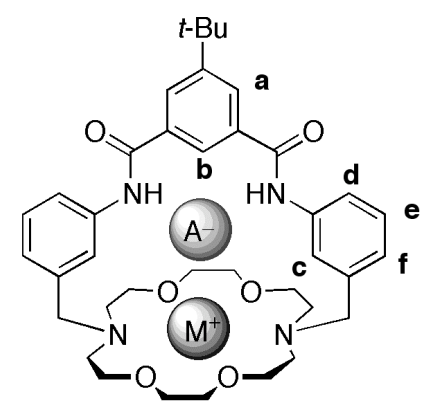

Scheme 1. Receptor $\mathbf{1 3}$ with bound salt. 


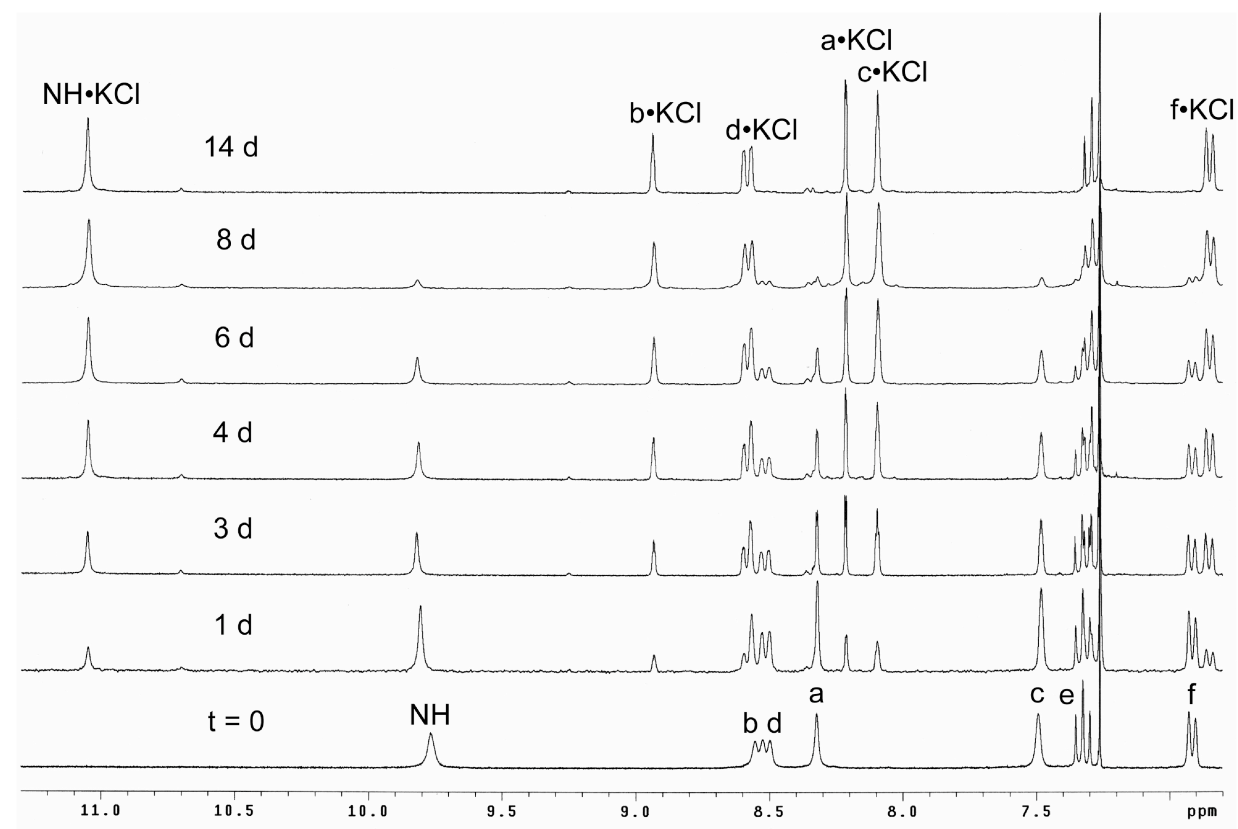

Figure 1. Partial ${ }^{1} \mathrm{H}$ NMR spectra of receptor 13 in $\mathrm{CDCl}_{3}$ at $295 \mathrm{~K}$ after addition of solid $\mathrm{KCl}$. See structure of 13 for proton labeling. (Reprinted with permission from ref. 21. Copyright 2001 American Chemical Society.)

\subsection{COMPLEXATION OF ALKALI HALIDES}

NMR titration experiments showed that the presence of an alkali metal cation greatly enhances halide-binding constants. [21] For example, the 13/ $\mathrm{Cl}^{-}$association constant in $\mathrm{CDCl}_{3}$ :DMSO- $d_{6}(85: 15)$ was increased from $80 \mathrm{M}^{-1}$ to $2.5 \times 10^{4} \mathrm{M}^{-1}$ by the presence of one molar equivalent of potassium tetraphenylborate. Additional NMR titration experiments showed that receptor $\mathbf{1 3}$ binds $\mathrm{KCl}$ better than $\mathrm{NaCl}$. X-ray analysis of the 13• $\mathrm{KCl}$ complex uncovered two independent but structurally similar complexes in the unit cell. One of the structures is shown in Figure 2. The salt is clearly a contact ion-pair whose $\mathrm{K}-\mathrm{Cl}$ distance of $2.989 \AA$ is slightly shorter than that observed in solid $\mathrm{KCl}$. We also obtained the X-ray structures of receptor $\mathbf{1 3}$ complexed with $\mathrm{LiCl}, \mathrm{LiBr}, \mathrm{NaCl}$, $\mathrm{NaBr}$, NaI, $\mathrm{KCl}, \mathrm{KBr}$, and $\mathrm{KI}$. [22,23] As expected, the larger anions do not fit perfectly inside the macrocyclic cavity, and so salt affinities are decreased. 


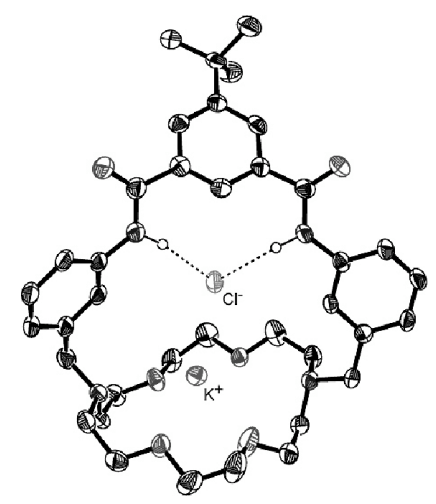

Figure 2. X-ray crystal structure of $\left[\mathbf{1 3} \cdot \mathrm{K}^{+} \bullet \mathrm{Cl}^{-}\right]$. (Reprinted with permission from ref. 21. Copyright 2001 American Chemical Society.)

We evaluated the ability of $\mathbf{1 3}$ to transport salts through a liquid organic membrane. [22] Transport experiments using a supported liquid membrane, and high salt concentration in the source phase, showed that $\mathbf{1 3}$ can transport alkali halides up to ten times faster than a monotopic cation receptor or a monotopic anion receptor. All transport systems exhibited the same qualitative order of ion selectivity, that is, for a constant anion, the cation selectivity order is $\mathrm{K}^{+}>\mathrm{Na}^{+}>\mathrm{Li}^{+}$, and for a constant cation, the anion transport selectivity order is $\mathrm{I}^{-}>\mathrm{Br}^{-}>\mathrm{Cl}^{-}$. These trends are in general agreement with the Hofmeister series, a solvation-based selectivity bias that is typically observed for liquid/liquid partitioning processes. [24] Transport fluxes decrease with the smaller, more charge-dense ions because they have a more unfavorable Gibbs free energy for aqueous to organic transfer. [25] It appears that the Hofmeister bias overwhelms any difference in receptor/salt binding affinities. Receptor $\mathbf{1 3}$ can also transport $\mathrm{NaCl}$ or $\mathrm{KCl}$ across vesicle membranes. [26] Chloride efflux from unilamellar vesicles was monitored using a chloride selective electrode and significant transport was observed even when the transporter/phospholipid ratio was as low as 1:2500. Mechanistic studies indicate that the facilitated efflux is due to the uncomplexed transporter diffusing into the vesicle and the transporter/salt complex diffusing out.

Receptor 13 was also evaluated in competitive solid/liquid extraction experiments. Remarkably, the cation selectivity order is strongly reversed when the receptor extracts solid alkali chlorides and bromides into organic solution; that is, the process is highly lithium selective. For a three-component mixture of solid $\mathrm{LiCl}, \mathrm{NaCl}$ and $\mathrm{KCl}$, the ratio of salts extracted and complexed to the receptor in $\mathrm{CDCl}_{3}$ was $94: 4: 2$, respectively. The same strong lithium selectivity was also observed in the case of a three-component mixture of solid $\mathrm{LiBr}, \mathrm{NaBr}$ and $\mathrm{KBr}$ where the ratio of extracted salts was 92:5:3. These contrasting results can be rationalized in terms of the equilibria that govern aqueous/organic extraction and solid/organic extraction (Scheme 2). Extraction of a salt, $\mathrm{M}^{+} \mathrm{A}^{-}$, into an organic phase mediated by a salt receptor, $\mathrm{R}$, can be considered as a two step process. The first equilibrium, $K_{p}$, involves partitioning of the salt into the organic phase and the second equilibrium, $K_{a}$, concerns association of the partitioned salt with the receptor. In the case of aqueous/organic extraction (eq 1), the equilibrium step controlling liquid membrane transport and determining cation selectivity is $K_{p}$ (which 
follows the Hofmeister series). The selectivity of the solid/liquid extraction mediated by 13 (eq 2) is also due to large differences in the partitioning equilibrium $K_{p}$, however, the order of $K_{p}$ for solid/liquid extraction is opposite to that for aqueous/organic extraction. Solid $\mathrm{LiCl}$ and solid $\mathrm{LiBr}$ are significantly more soluble in non-polar solvents than the corresponding sodium or potassium salts. The bonding in alkali halides, including lithium halides, is predominantly ionic, however, many lithium salts are known to have unusually low melting points and good solubilities in organic solvents. [27] This is due to the small size of the lithium cation and the molecular nature of its associated ionpairs. The mechanism for salt transfer from aqueous to organic is not the same as the mechanism for solid/organic partitioning. Aqueous/organic partitioning involves the transfer of individual, hydrated ions that subsequently associate in the organic phase; whereas, solid/organic partitioning more likely involves the transfer of associated ionpairs from solid to organic phase. In this latter case, it appears that receptor $\mathbf{1 3}$ binds the solubilized ion-pairs, and retains them in organic solution, which converts the large differences in solid/organic $K_{p}$ into a potentially useful, lithium-selective extraction process. These results suggest that solid/liquid extraction may be a purification strategy that is applicable to other salts. The aim would be to design and construct multitopic receptors with an ability to extract the solid salts as associated ion-pairs.

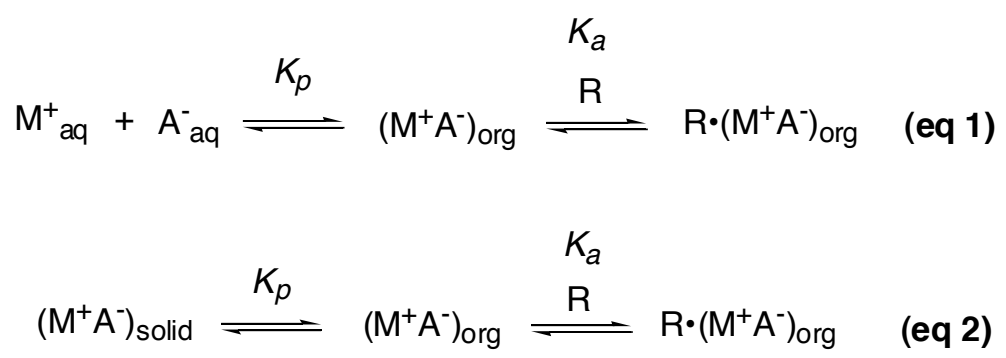

Scheme 2. Two-step process for extraction of salt, $\mathrm{M}^{+} \mathrm{A}^{-}$, using a salt receptor $\mathrm{R}$. Aqueous/organic extraction (eq 1) and solid/organic extraction (eq 2). (Reprinted with permission from ref. 23. Copyright 2004 American Chemical Society.)

In an effort to increase salt binding affinities we collaborated with the Gale research group and prepared the second-generation macrobicyclic receptor 14, which contains a bridging 2,5-diamidopyrrole group. [28] NMR titration experiments indicated that 14 has a three-fold higher affinity for $\mathrm{Cl}^{-}$than 13 . The $14 / \mathrm{Cl}^{-}$association constant is hardly changed by the presence of one molar equivalent of $\mathrm{Na}^{+}$ions but it is increased substantially by the presence of $\mathrm{K}^{+}$ions. As expected, an X-ray structure of the $[14 \cdot \mathrm{NaCl}$ ] complex confirmed that the receptor binds $\mathrm{NaCl}$ as a contact ion-pair (Figure 3). The crystal structure shows clearly why 14 exhibits enhanced $\mathrm{Cl}^{-}$affinity relative to 13. Not only does the $\mathrm{Cl}^{-}$form hydrogen bonds with both amide but also with the pyrrole $\mathrm{NH}$. The $\mathrm{Na}-\mathrm{Cl}$ distance of $2.65 \AA$ is shorter than the $\mathrm{Na}-\mathrm{Cl}$ distance when sodium chloride is bound in $\mathbf{1 3}(2.70 \AA)$. 

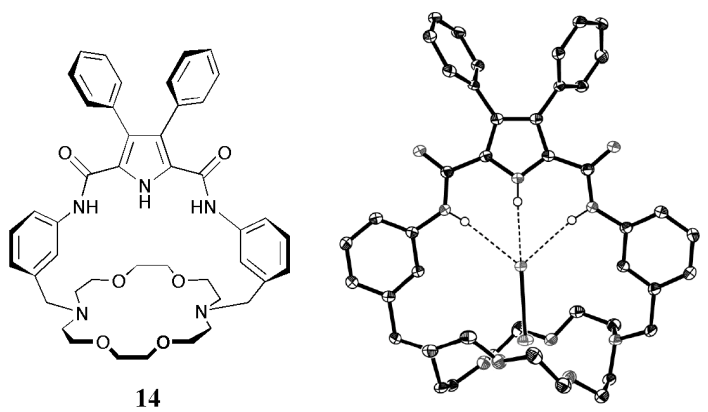

Figure 3. Chemical structure of $\mathbf{1 4}$ and $\mathrm{X}$-ray structure of $\left[\mathbf{1 4} \bullet \mathrm{Na}^{+} \bullet \mathrm{Cl}^{-}\right]$.

\subsection{COMPLEXATION OF ALKYLAMMONIUM SALTS}

Receptor $\mathbf{1 3}$ can also bind monoalkylammonium salts as contact ion-pairs. [29] The Xray structure of the $\mathbf{1 3} \cdot \mathrm{MeNH}_{3} \mathrm{Cl}$ complex is shown in Figure 4. The methylammonium cation fits deeply into the binding pocket of the receptor and forms three hydrogen bonds; one to a crown oxygen, one to a crown nitrogen, and one to the chloride which is in turn hydrogen bonded to the two receptor NH residues. The X-ray structure suggests that the macrocyclic cavity can only accommodate alkylammonium cations with small or narrow alkyl groups. This hypothesis was tested by measuring the ability of receptor $\mathbf{1 3}$ to bind various alkylammonium chloride salts in $85: 15 \mathrm{CDCl}_{3}:$ DMSO- $d_{6}$, a solvent system where host/guest exchange is rapid on the NMR time scale. As shown in Table 1, the association constant for $\mathrm{NBu}_{4}{ }^{\circ} \mathrm{Cl}$ is $50 \mathrm{M}^{-1}$. A control experiment with $\mathrm{NBu}_{4} \mathrm{PF}_{6}$ confirmed that the tetrabutylammonium cation does not bind to the receptor; thus, the association constant is a measure of $\mathrm{Cl}^{-}$affinity for $\mathbf{1 3}$. The association constant for $\mathrm{Et}_{2} \mathrm{NH}_{2} \cdot \mathrm{Cl}$ is $10 \mathrm{M}^{-1}$ which indicates that the diethylammonium cation lowers the $\mathrm{Cl}^{-}$ affinity by sequestering the $\mathrm{Cl}^{-}$away from receptor 13. In the case of $i-\mathrm{PrNH}_{3} \cdot \mathrm{Cl}$ and $n$ $\mathrm{PrNH}_{3}{ }^{\circ} \mathrm{Cl}$ the association constants are $2.0 \times 10^{2}$ and $2.0 \times 10^{4} \mathrm{M}^{-1}$, respectively. In the case of $n-\mathrm{PrNH}_{3}{ }^{\circ} \mathrm{Cl}$ binding, a Job plot indicated that the complex stoichiometry is 1:1. The one hundred-fold selectivity for $n-\mathrm{PrNH}_{3}{ }^{\bullet} \mathrm{Cl}$ over $i-\mathrm{PrNH}_{3}{ }^{\bullet} \mathrm{Cl}$ was confirmed by a competitive binding experiment where ${ }^{1} \mathrm{H}$ NMR showed that one molar equivalent of $n$ $\mathrm{PrNH}_{3} \bullet \mathrm{Cl}$ can completely displace $i-\mathrm{PrNH}_{3} \bullet \mathrm{Cl}$ from a complex of $\left[\mathbf{1 3} \bullet i-\mathrm{PrNH}_{3} \bullet \mathrm{Cl}\right]$ in $\mathrm{CDCl}_{3}$. In addition, receptor $\mathbf{1 3}$ has an affinity for $n-\mathrm{PrNH}_{3} \cdot \mathrm{Cl}$ that is two hundred times stronger than for $n-\mathrm{PrNH}_{3} \bullet \mathrm{AcO}$ and $n-\mathrm{PrNH}_{3} \bullet p$-TsO (Table 1). The relatively large changes in chemical shift for several diagnostic receptor hydrogens upon salt binding provides good evidence that the mode of binding in solution is very similar to that observed in the solid state. 


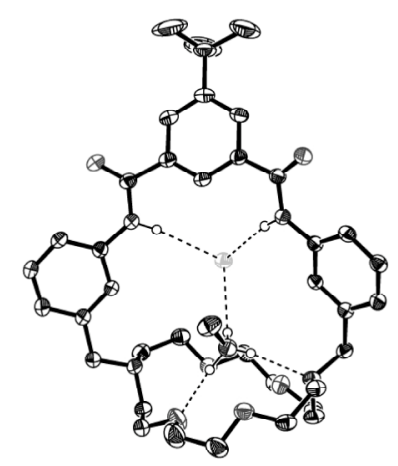

Figure 4. X-ray crystal structure of $\left[13 \cdot \mathrm{MeNH}_{3}{ }^{+} \mathrm{Cl}^{-}\right]$. (Reprinted with permission from ref. 29. Copyright 2003 American Chemical Society.)

TABLE 1. Association constants $\left(K_{\mathrm{a}}\right)$ and chemical shift changes (ㅁ) for receptor 13

\begin{tabular}{ccccc}
\hline Guest & $K_{\mathrm{a}}\left(\mathrm{M}^{-1}\right)^{a}$ & $\mathrm{NH} \square \square^{p}$ & $\mathrm{H}_{\mathrm{b}} \square \square^{p}$ & $\mathrm{H}_{\mathrm{c}} \square \square^{p}$ \\
\hline $\mathrm{Bu}_{4} \mathrm{~N}^{\circ} \mathrm{Cl}$ & 50 & +0.90 & +0.44 & +0.44 \\
$n-\mathrm{PrNH}_{3} \bullet \mathrm{Cl}$ & $2.0 \times 10^{4}$ & +1.00 & +0.11 & +0.39 \\
$i-\mathrm{PrNH}_{3} \bullet \mathrm{Cl}$ & $2.0 \times 10^{2}$ & +1.02 & +0.28 & +0.42 \\
$\mathrm{Et}_{2} \mathrm{NH}_{2} \bullet \mathrm{Cl}$ & 10 & +0.78 & +0.19 & +0.31 \\
$n-\mathrm{PrNH}_{3} \bullet p-\mathrm{TsO}$ & $1.0 \times 10^{2}$ & +0.30 & -0.31 & +0.22 \\
$\mathrm{Bu}_{4} \mathrm{~N}^{\circ} p-\mathrm{TsO}$ & 4 & +0.08 & +0.01 & +0.08 \\
$n-\mathrm{PrNH}_{3} \bullet \mathrm{AcO}$ & $1.2 \times 10^{2}$ & +1.10 & -0.11 & +0.25 \\
$\mathrm{Bu}_{4} \mathrm{~N} \bullet \mathrm{AcO}$ & 20 & +1.82 & +0.44 & +0.45
\end{tabular}

${ }^{a}$ In $\mathrm{CDCl}_{3}:$ DMSO- $d_{6} 85: 15, \mathrm{~T}=295 \mathrm{~K}$, initial $[\mathbf{1 3}]=10 \mathrm{mM}$. Uncertainty $\pm 40 \%$. ${ }^{b}$ Change in receptor chemical shift (ppm) after addition of $200 \mathrm{mM}$ guest salt. See structure of $\mathbf{1 3}$ for proton labeling.

\subsection{COMPLEXATION OF SALTS WITH TRIGONAL OXYANIONS}

Most recently we have evaluated the ability of $\mathbf{1 3}$ to recognize alkali $\mathrm{AcO}^{-}$and $\mathrm{NO}_{3}^{-}$ salts. We were particularly interested in seeing how these trigonal oxyanions, with lone pair and $\pi$-electron density, simultaneously interact with the NH residues on $\mathbf{1 3}$ and the bound alkali metal cation. We were motivated by a report by Hay and coworkers who found crystallographic evidence indicating that trigonal oxyanions (like $\mathrm{NO}_{3}{ }^{-}$and $\mathrm{AcO}^{-}$) prefer to form hydrogen bonds with $\mathrm{R}-\mathrm{H}$ acceptors that have $\mathrm{H} \cdots \mathrm{O}-\mathrm{A}$ angles near $120^{\circ}$ and $\mathrm{R}-\mathrm{H} \cdots \mathrm{O}-\mathrm{N}$ dihedral angles near $0^{\circ}$ (Scheme 3). [30] In other words, the donor hydrogen atom lies within the plane of the trigonal anion. Hay calculates that the preference for hydrogen bonding to the oxygen lone pairs over the $\pi$-electron density is about $2 \mathrm{kcal} / \mathrm{mol}$. [31] 


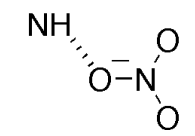

$\mathrm{H}$-bonding with lone pair electrons

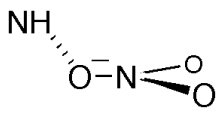

$\mathrm{H}$-bonding with r-electrons

Scheme 3. Hydrogen bonding with nitrate lone pair electrons (H-O-N-O dihedral angle $0^{\circ}$ ) is favored over hydrogen bonding with $\pi$-electrons ( $\mathrm{H}-\mathrm{O}-\mathrm{N}-\mathrm{O}$ dihedral angle $90^{\circ}$ ).

Shown in Figures 5-7 are three X-ray structures of receptor 13 complexed with $\mathrm{NaNO}_{3}, \mathrm{KNO}_{3}$, or $\mathrm{LiNO}_{3}$. [32] The X-ray structure of $\mathbf{1 3} \cdot \mathrm{NaNO}_{3}$ (Figure 5) shows that the $\mathrm{NO}_{3}{ }^{-}$is located deep inside the macrocyclic cavity and chelates the bound $\mathrm{Na}^{+}$. The receptor $\mathrm{NH}$ residues form hydrogen bonds with the non-chelating $\mathrm{NO}_{3}{ }^{-}$and the two $\mathrm{H}$ $\mathrm{O}-\mathrm{N}-\mathrm{O}$ dihedral angles are $34^{\circ}$ and $78^{\circ}$. In the case of solid-state $13 \cdot \mathrm{KNO}_{3}$, the larger $\mathrm{K}^{+}$ cation forces the chelating $\mathrm{NO}_{3}{ }^{-}$to sit further out of the receptor cavity, which gives the $\mathrm{NO}_{3}{ }^{-}$more freedom to move (Figure 6). Indeed, the $\mathrm{NO}_{3}{ }^{-}$flips between two unequally occupied positions between the two receptor NH residues. The $70 \%$ occupancy structure is shown and has two quite different intermolecular $\mathrm{N} \cdots \mathrm{O}$ distances to the non-chelating $\mathrm{NO}_{3}{ }^{-}$oxygen and two quite different H-O-N-O dihedral angles of $15^{\circ}$ and $70^{\circ}$. This asymmetrical positioning of the $\mathrm{NO}_{3}{ }^{-}$allows the receptor to better align one of its two $\mathrm{NH}$ residues with the more basic lone pair electrons, thus forming a stronger hydrogen bond. The X-ray structure of the $13 \cdot \mathrm{LiNO}_{3}$ complex (Figure 7) differs from the sodium and potassium analogs in a number of ways. The $\mathrm{Li}^{+}$is coordinated by five heteroatoms, one nitrogen and two oxygens from the crown and two water oxygens (derived adventitiously from the atmosphere during the crystallization process). One of the water molecules bridges the cation and anion. The receptor $/ \mathrm{NO}_{3}{ }^{-}$orientation is rotated almost $90^{\circ}$, compared to the sodium and potassium structures, which means that the receptor $\mathrm{NH}$ residues are directed primarily towards the two lone pairs on one of the $\mathrm{NO}_{3}{ }^{-}$ oxygens (the two $\mathrm{H}-\mathrm{O}-\mathrm{N}-\mathrm{O}$ dihedral angles are $28^{\circ}$ and $37^{\circ}$ ), and the bridging water $\mathrm{OH}$ is directed towards the $\mathrm{NO}_{3}^{-}$oxygen's -electrons ( $\mathrm{H}-\mathrm{O}-\mathrm{N}-\mathrm{O}$ dihedral angle of $90^{\circ}$ ). Thus, with these three receptor $/ \mathrm{NO}_{3}{ }^{-}$salt structures, the directionality of the hydrogen bonding between the complexed $\mathrm{NO}_{3}{ }^{-}$and the receptor $\mathrm{NH}$ is strongly influenced by the identity of the counter cation.

It appears that $\mathrm{NO}_{3}{ }^{-}$orientation is controlled by a complex interplay of steric factors, coordination bonding to the metal cation, and hydrogen bonding with the receptor NH residues. This latter factor includes a modest preference to direct the two receptor NH residues towards the more basic oxyanion lone pairs. The directionality can be overwhelmed by stronger bonding effects such as ion-pairing. For example, in the case of the sodium and potassium structures, the $\mathrm{NO}_{3}{ }^{-}$is directly chelated to the counter cation, but this is only achieved by twisting the receptor $/ \mathrm{NO}_{3}{ }^{-}$orientation such that one or both of the receptor $\mathrm{NH}$ residues are pointing substantially at the $\mathrm{NO}_{3}{ }^{-}$-surface. This weaker hydrogen bonding arrangement is more than offset by the formation of strong coordination bonds. 


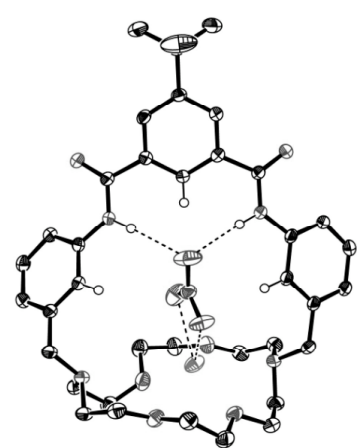

Figure 5. X-ray crystal structure of $\left[\mathbf{1 3} \cdot \mathrm{Na}^{+} \cdot \mathrm{NO}_{3}{ }^{-}\right]$. (Reprinted with permission from ref. 32. Copyright 2004 American Chemical Society.)

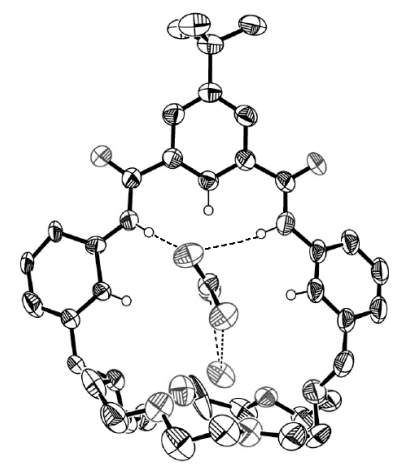

Figure 6. X-ray crystal structure of $\left[\mathbf{1 3} \cdot \mathrm{K}^{+} \cdot \mathrm{NO}_{3}{ }^{-}\right]$. The $70 \%$ occupancy orientation is shown for nitrate. (Reprinted with permission from ref. 32. Copyright 2004 American Chemical Society.)

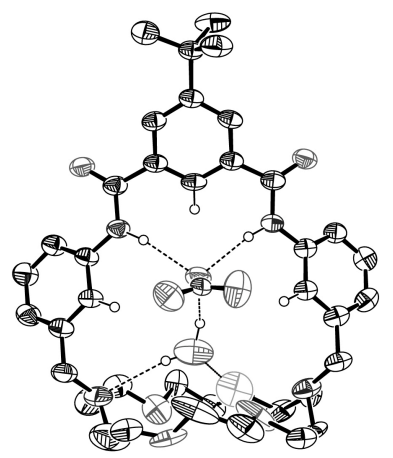

Figure 7. X-ray crystal structure of $\left[\mathbf{1 3} \cdot \mathrm{Li}^{+} \bullet 2 \mathrm{H}_{2} \mathrm{O} \bullet \mathrm{NO}_{3}{ }^{-}\right]$. Absent is a second water molecule that is located underneath the crown and coordinated to the $\mathrm{Li}^{+}$. (Reprinted with permission from ref. 32 . Copyright 2004 American Chemical Society.) 
The preceding X-ray data provides a structural basis for interpreting the following unusual NMR data. Listed in Table 2 are the changes in ${ }^{1} \mathrm{H}$ NMR chemical shifts for the receptor signals upon complexation with a variety of salts. In the case of $\mathrm{NaCl}, \mathrm{NaAcO}$ and $\mathrm{KAcO}$, the $\mathrm{NH}$ signals moves downfield $0.7-0.9 \mathrm{ppm}$ as expected. [33] On the other hand, complexation with the nitrate salts induces quite different changes in chemical shift. In particular, the NH signal moves upfield by $0.05-0.22 \mathrm{ppm}$ (Table 2 and Figure 8). To the best of our knowledge, an upfield shift of a neutral receptor amide NH signal upon anion complexation is unprecedented. Another unusual change is the large upfield shift of equivalent protons $\mathbf{c}$ (see Table 2 for a comparison of complexed-induced-shifts). These unusual changes in chemical shift upon complexation indicate that the magnetic shielding environment around the $\mathrm{NO}_{3}{ }^{-}$is anisotropic. Indeed, we used Density Functional Theory to calculate the shielding surface around the $\mathrm{NO}_{3}{ }^{-}$ anion and found that it is deshielding around the peripheral plane of the molecule and shielding in a region above the central nitrogen (Scheme 4).

TABLE 2. Change in ${ }^{1} \mathrm{H}$ NMR chemical shift ( $\mathrm{TD}$ ) of selected protons upon saturation of $\mathbf{1 3}$ with salt. ${ }^{a}$

\begin{tabular}{ccccc}
\hline \multirow{2}{*}{ Salt } & \multicolumn{4}{c}{ CD(ppm) ${ }^{b}$} \\
& & b & NH & c \\
\hline $\mathrm{NaCl}$ & +0.02 & +0.66 & +0.94 & +0.87 \\
$\mathrm{NaAcO}$ & 0.00 & +0.45 & +0.72 & +0.11 \\
$\mathrm{KAcO}$ & -0.03 & +0.48 & +0.87 & +0.05 \\
$\mathrm{NaNO}_{3}$ & 0.00 & +0.21 & -0.22 & -0.18 \\
$\mathrm{KNO}_{3}$ & 0.00 & +0.32 & -0.05 & -0.21 \\
$\mathrm{LiNO}_{3}$ & -0.01 & +0.20 & -0.22 & -0.09 \\
$\mathrm{Bu}_{4} \mathrm{NNO}_{3}{ }^{c}$ & -0.03 & +0.04 & +0.51 & +0.27
\end{tabular}

${ }^{a}$ Solid salt extracted into solution of $\mathbf{1 3}(10 \mathrm{mM})$ in $\mathrm{CDCl}_{3}$ at $\mathrm{T}=295 \mathrm{~K} .{ }^{b}$ See structure of $\mathbf{1 3}$ for proton labeling. $\square \square=$ $\square$ 13•salt - $\square$ 13. ${ }^{c}$ Data obtained after mixing $150 \mathrm{mM}$ $\mathrm{Bu}_{4} \mathrm{NNO}_{3}$ and $10 \mathrm{mM} 13$ in $\mathrm{CDCl}_{3}$.

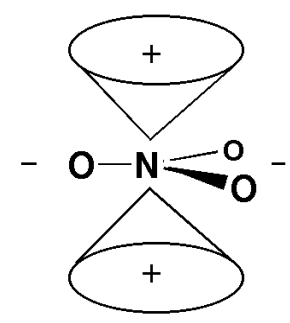




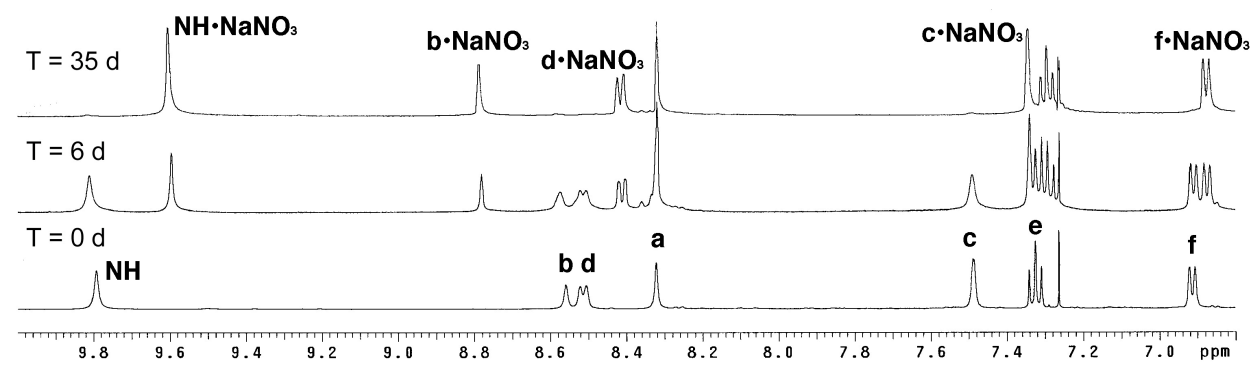

Figure 8. Partial ${ }^{1} \mathrm{H}$ NMR spectra of receptor 13 in $\mathrm{CDCl}_{3}$ at $295 \mathrm{~K}$ after addition of solid $\mathrm{NaNO}_{3}$. See structure of $\mathbf{1 3}$ for proton labeling. (Reprinted with permission from ref. 32. Copyright 2004 American Chemical Society.)

Having established that $\mathrm{NO}_{3}^{-}$has an anisotropic shielding surface, the next question was whether the complexation-induced changes in chemical shifts that are listed in Table 2 can be used to elucidate the structure of the receptor/salt complexes in solution. In some cases, the solution state NMR data seems to match with the solid state structure. For example, the signals for the $\mathrm{NH}$ and $\mathbf{c}$ protons in $\mathbf{1 3}$ move upfield by -0.22 and $-0.18 \mathrm{ppm}$, respectively, when $\mathbf{1 3}$ is saturated with $\mathrm{NaNO}_{3}$. The X-ray structure of 13. $\mathrm{NaNO}_{3}$ (Figure 5) suggests that this is because the $\mathrm{NH}$ and $\mathbf{c}$ protons are located in shielding zones above and below the plane of the encapsulated $\mathrm{NO}_{3}^{-}$. However, when $\mathbf{1 3}$ is saturated with $\mathrm{LiNO}_{3}$, the solution state NMR data does not appear to match with the solid state structure. For example, the receptor $\mathrm{NH}$ and $\mathbf{c}$ protons move upfield by -0.22 and $-0.09 \mathrm{ppm}$, respectively, but the X-ray structure of $\mathbf{1 3} \cdot 2 \mathrm{H}_{2} \mathrm{O} \cdot \mathrm{LiNO}_{3}$ (Figure 7) shows that the $\mathrm{NH}$ and $\mathbf{c}$ protons are located in the peripheral plane around the encapsulated $\mathrm{NO}_{3}{ }^{-}$(deshielding zones). This suggests that the X-ray structure is not the predominant structure in solution. Evidence in favor of this hypothesis was gained from a variable temperature ${ }^{1} \mathrm{H}$ NMR study of the complex. The system undergoes dynamic exchange because at low temperature the spectrum splits into three sets of signals. Shown in Figure 9 are the signals for the NH residues at $213 \mathrm{~K}$. The NH peak at $10.09 \mathrm{ppm}$ corresponds to free receptor; whereas, the upfield peak at around $9.8 \mathrm{ppm}$ is attributed to a dehydrated $13 \cdot \mathrm{LiNO}_{3}$ complex with a structure that is analogous to $13 \cdot \mathrm{NaNO}_{3}$ in Figure 5 (i.e., the $\mathrm{NO}_{3}{ }^{-}$is chelated to the $\mathrm{Li}^{+}$inside the cavity of the receptor). The downfield $\mathrm{NH}$ peak at $10.15 \mathrm{ppm}$ is attributed to a hydrated complex with a structure that is very similar to $\mathbf{1 3} \cdot 2 \mathrm{H}_{2} \mathrm{O} \cdot \mathrm{LiNO}_{3}$ in Figure 7 . The relative ratio of these three signals depends on the amount of water in the sample. As depicted in Figure 9, the peak at $9.8 \mathrm{ppm}$ (corresponding to dehydrated salt complex with chelated $\mathrm{LiNO}_{3}$ ) is diminished when water is added to the sample.

The large complexation-induced changes in ${ }^{1} \mathrm{H}$ chemical shift for the protons that line the cavity of receptor $\mathbf{1 3}$ indicate how the oxyanion salts bind to the receptor cavity in solution. In principle, the direction and magnitude of the shieldings can be used to elucidate the relative orientation of the encapsulated anisotropic anion, however, this requires quantitative mapping of the shielding surface around the anion (which we have done in the case of $\mathrm{NO}_{3}^{-}$) and knowledge of the receptor/salt dynamics. In certain cases (e.g., the $13 \cdot \mathrm{LiNO}_{3}$ system above), the signal averaging due to dynamic exchange can be eliminated by acquiring the NMR spectrum at low temperature. Overall, the use of 
ditopic salt receptors, such as $\mathbf{1 3}$, to solubilize salts as discrete, slowly exchanging, associated ion-pairs, is a new and effective way to characterize the structure of ion-pairs.

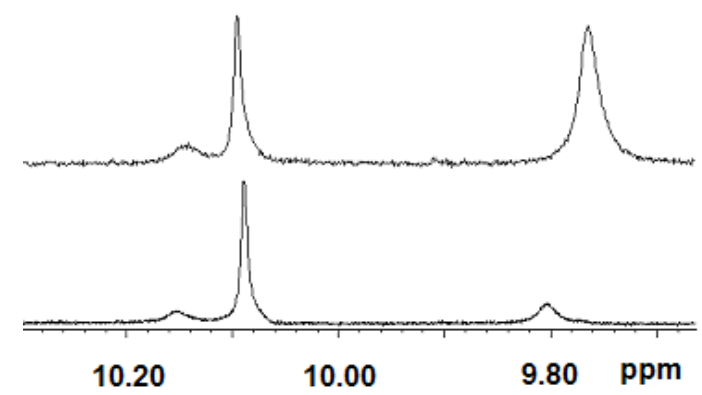

Figure 9. Partial ${ }^{1} \mathrm{H}$ NMR spectrum of $\mathbf{1 3} \cdot \mathrm{LiNO}_{3}$ at $213 \mathrm{~K}$. Top: sample prepared by solid-liquid extraction using freshly opened $\mathrm{CDCl}_{3}$. Bottom: sample prepared with water-saturated $\mathrm{CDCl}_{3}$. (Reprinted with permission from ref. 32. Copyright 2004 American Chemical Society.)

\section{Summary}

In the future, salt-binding receptors will be employed in various separation and sensing applications. The work described in this chapter demonstrates that ditopic receptors, with an ability to bind the salts as contact ion-pairs, have particularly attractive properties as extraction and transport agents. Another future direction is the utilization of salts as "molecular glue" to assemble complex supramolecular structures that have dynamic properties and the capability to behave as molecular machines.

\section{Acknowledgements}

I warmly thank the students and postdoctoral associates in my research group who made the excellent experimental contributions described in this chapter. In particular, I acknowledge the work of Dr. Joseph M. Mahoney. This study was supported by the University of Notre Dame and the National Science Foundation.

\section{References}

1. Shukla, R., Kida, T., and Smith, B.D., Org. Lett. 2 (2000), 3039-3248.

2. Gale, P.A. Coord. Chem. Rev. 240 (2003), 191-221.

3. Smith, B.D. and Mahoney, J.M. Encyclopedia of Supramolecular Chemistry, Marcell

Dekker: New York, 2004, 1291-1294. 
4. Mahoney, J.M., Davis, J.P., and Smith, B.D., In, Fundamentals and Applications of Anion Separations, Moyer, B.A., Singh, R., Eds.; ACS Symposium Series, ACS: Washington, 2004, 115-124.

5. Beer, P.D., and Gale, P.A. Angew. Chem. Int. Ed. 40 (2001), 486-516.

6. Kirkovits, G., J., Shriver, J.A., Gale, P.A., and Sessler, J.L. J. Incl. Phenom. Macrocycl. Chem. 40 (2001), 69-75.

7. Rudkevich, D.M., Brzozka, Z., Palys, M., Visser, H.C., Verboom, W.; and Reinhoudt, D.N. Angew. Chem. Int. Ed. Engl. 33 (1994), 467-469.

8. Beer, P.D., Drew, M.G., Knubley, R.J., and Ogden, M.I. J. Chem. Soc. Dalton Trans. (1995), 3117-3123.

9. Tumcharern, G., Tuntulani, T., Coles, S.J., Hursthouse, M.B., and Kilburn, J.D. Org. Lett. 5 (2003), 4971-4974.

10. Savage, P.B., Holmgren, S.K., and Gellman, S.H. J. Am. Chem. Soc. 116 (1994), 4069-4070.

11. Arafa, E.A., Kinnear, K.I., and Lockhart, J.C. Chem. Commun. (1992), 61-64.

12. Tozawa, T., Misawa, Y., Tokita, S., and Kubo, Y. Tetrahedron Lett. 41 (2000), 5219-5223.

13. Reetz, M.T., Niemeyer, C.M., and Harms, K. Angew. Chem. Int. Ed. Engl. 30 (1991), 1474-1476.

14. Flack, S.S., Chaumette, J-L., Kilburn, J.D., Langley, and G.J. Webster, M. Chem. Commun. (1993), 399-400.

15. Deetz, M.J., Shang, M., and Smith, B.D. J. Am. Chem. Soc. 122 (2000), 6201-6207.

16. Wisner, J.A., Beer, P.D., Berry, N.G., and Tomapatanaget, B. Proc. Natl. Acad. Sci. USA 99 (2002), 4983-4986.

17. Shi, X., Mullaugh, K.M., Fettinger, J.C., Jiang, Y., Hofstadler, S.A., and Davis, J.T. J. Am. Chem. Soc. 125 (2003), 10830-10841.

18. Manisikkamäki, H., Nissinen, M., Schalley, C.A., and Rissanen, K. New. J. Chem. 27 (2003), 88-97.

19. Bourgeois, J., Fujita,M., Kawano, M., Sakamoto, S., and Yamaguchi, K. J. Am. Chem. Soc. 125 (2003), 9260-9261.

20. Atwood, J.L., and Szumna, A. Chem. Comm. (2003) 940-941.

21. Mahoney, J.M., Beatty, A.M., and Smith, B.D. J. Am. Chem. Soc. 123 (2001), $5847-$ 5848.

22. Mahoney, J.M., Nawaratna, G.U., Beatty, A.M., Duggan, P.J., and Smith, B. D. Inorg. Chem. 43 (2004), 5902-5907.

23. Mahoney, J.M., Beatty, A.M., and Smith, B.D. Inorg. Chem. 43 (2004), ASAP.

24. Levitskaia, T., Marquez, M., Sessler, J.L., Shriver, J.A., Vercouter, T., and Moyer, B.A. Chem. Comm. (2003), 2248-2249.

25. Olsher, U., Kankins, M., Kim, Y.D., and Bartsch, R.A. J. Am. Chem. Soc. 115 (1993), 3370-3371.

26. Koulov, A.V., Mahoney, J.M., Beatty, A.M., and Smith, B.D. Org. Biomol. Chem. 1 (2003), 27-29.

27. Snaith, R. and Wright, D.S., In Lithium Chemistry - A Theoretical and Experimental Overview, Sapse, A.-M., Von Rogué Schleyer, P., Eds.; Wiley: New York, 1995, Ch. 8.

28. Mahoney, J.M., R. Marshall, R.A., Beatty, A.M., Smith, B.D., Camiolo, S., and Gale, P.A. J. Supramol. Chem. 1 (2001), 289-292. 
29. Mahoney, J.M., Davis, J.P., and Smith, B.D. J. Org. Chem. 68 (2003), 9819-6820.

30. Hay, B.P., Dixon, D.A., Bryan, J.C., and Moyer, B.A. J. Am. Chem. Soc. 124 (2002), 182-183.

31. Hay, B.P., Gutowski, M., Dixon, D.A., Garza, J., Rubicelia, R., and Moyer, B.A. J. Am. Chem. Soc. 126 (2004), 7925-7934.

32. Mahoney, J.M., Stucker, K.A., Jiang, H., Carmichael, I., Brinkmann, N.R., Beatty, A.M., and Smith, B.D., manuscript submitted.

33. Konrat, R., Tollinger, M., Kontaxis, G., and Kräutler, B. Monatsh. Chem. 130 (1999), 961-982. 